\title{
Underground Solution Canyons in the Central Kentucky Karst, U.S.A.
}

\author{
By Righard A. Watson ${ }^{1}$ )
}

With 4 figures in the text

\section{Introduction}

Solution canyons are underground voids 1 to $15+$ meters wide, 3 to $45+$ meters high, and 30 to $300+$ meters long. Their floors are usually stepped, with the ceiling remaining at approximately one level while the overall size and height generally increases downstream (figure 1). Their courses are slightly sinuous, with some angular turns at joint intersections. They occur directly below or slightly offset from and

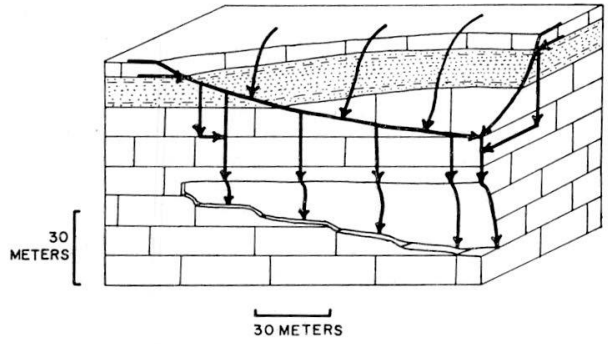

Fig. 1

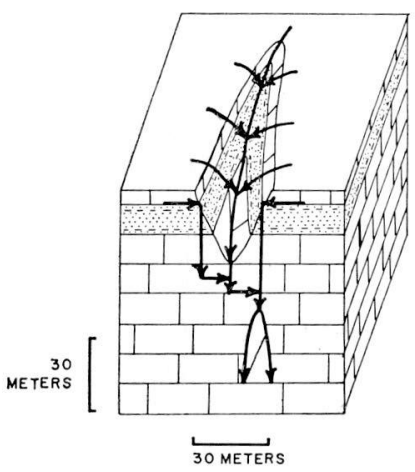

Fig. 2

Fig. 1. Idealized Block Diagram of Re-Entrant Valley and Underlying Solution Canyon: Longitudinal-Section. Arrows indicate concentration of surface and underground water flow.

Fig. 2. Idealized Block Diagram of Re-Entrant Valley and Underlying Solution Canyon: Cross-Section. Arrows indicate concentration of surface and underground water flow.

1) Cave Research Foundation: Department of Philosophy, Washington University, St. Louis, Missouri 63130, U.S.A. 
roughly parallel to the thalwegs of overlying re-entrant valleys which intersect the sandstone caprock of the ridges and are tributary to the major karst valleys. A section across a re-entrant valley and an underlying solution canyon would show a rough hour-glass shape (figure 2). The walls of solution canyons are generally vertically fluted.

\section{Habitat of the Solution Canyons}

The Central Kentucky Karst is an area of about 600 square kilometers lying on Mississippian rocks in south-central Kentucky along the edge of the Cincinnati Arch in the Interior Lowland Province, its center 160 kilometers south of Louisville. It is an integral part of a karsted limestone belt which extends from southern Indiana south through Kentucky into Tennessee along the entire west flank of the Cincinnati Arch. The Central Kentucky Karst hosts a through-flowing master karst stream, the Green River, and is composed of three major physiographic units separated by two major escarpments. In the southeast portion is the low-lying Sinkhole Plain at an average elevation of 195 meters. It is separated from the central Mammoth Cave Plateau at an average elevation of 255 meters by the northeast trending Dripping Springs Escarpment. North of the Green River which flows along the north edge of the Plateau at an elevation of 127.5 meters, the Pottsville Escarpment also trends northeast and separates the Plateau from the Hilly Country which has a maximum elevation of nearly 270 meters. Mammoth Cave National Park encloses portions of the Plateau and the Hilly Country, but unfortunately not of the Sinkhole Plain which lies in close physiographic relation.

Field investigations over the past 10 years have been made in the central part of the Mammoth Cave Plateau (figure 3). Here are found three major northwest-trending ridges - Joppa Ridge, Mammoth Cave Ridge, and Flint Ridge - with ridge-top elevations of approximately 255 meters. The ridges are over 8 kilometers long and vary in width from 0.9 to 1.4 kilometers. The surface of these mesa-like ridges dips gradually to the west. They are separated by two major karst valleys, also varying in width from 0.9 to 1.4 kilometers, with valley floor elevations from 165 to 210 meters. Eaton-Houchins Valley separates Flint Ridge from Mammoth Cave Ridge; Doyle Valley separates Mammoth Cave Ridge from Joppa Ridge. Beneath Flint Ridge is the Flint Ridge Cave System of which more than 88.5 continuous kilometers of pssages have so far been mapped (Smith, 1964). Beneath Mammoth Cave Ridge lies the famous Mammoth Cave System of 

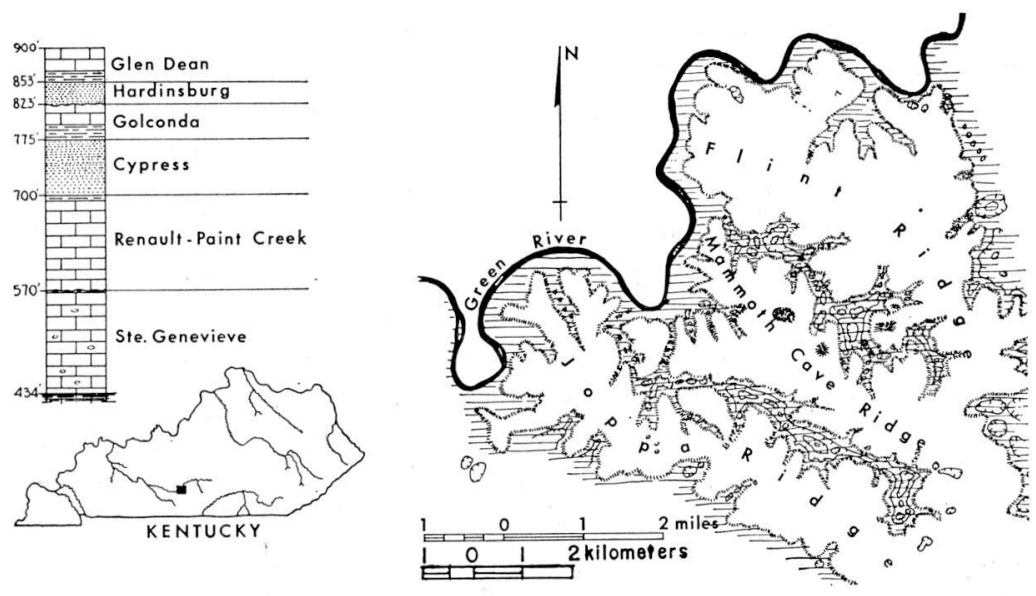

Fig. 3. The Mammoth Cave Plateau on Mississippian Rocks.

which some 72.5 continuous kilometers have been mapped. These are the two longest cave systems known on the North American continent. Recent exploration in the Flint Ridge System under Houchins Valley has penetrated to within 100 meters of passages in the Mammoth Cave System, and it is without question that the two systems will one day be joined. No extensive cave system is known to exist beneath Joppa Ridge, though geologic and physiographic relations indicate that there must be one there.

The ridges are held up by the capping Cypress Sandstone with enclosed layers of impermeable shale. This sandstone is up to 22.5 meters thick and overlies about 90 meters of cavernous Renault-Paint Creek and Ste. Genevieve Limestone (figure 3). The most recent stratigraphic study is found in Pohl and Cushman (1964). The formations dip gently to the northwest. The base of the Cypress Sandstone approximately follows the 210 meter contour, which thus is an important guideline in the interpretation of underground features. The average annual rainfall for the region is 115 to 130 centimeters, mean annual temperature is 12.2 to $13.3^{\circ} \mathrm{C}$., and the Plateau is covered with a temperate deciduous forest of oak-hickory and southern hardwoods, typical of the Interior Low Plateaus.

Throughout the cave systems, horizontal passages are intersected by solutional vertical shafts that are genetically unrelated to the passages. Vertical shafts are roofed, cylindrical voids of nearly uniform dimensions from top to bottom. They range in width from 0.9 to over 15 meters, and in height from 3 to over 45 meters. Ceilings are usually 
flat, and often contain floorless ceiling channels 10 to 30 centimeters deep. The walls of vertical shafts are usually vertically fluted. Their floors are often saucer-shaped, and all have small elliptical or canyonshaped drains which are seldom of dimensions large enough for a man to enter. Shafts sometimes form in coalescing groups, forming a void with a serrate plan. Since vertical shafts occur apart from, or indiscriminately intersecting one or more levels of horizontal cave passages, Pohl (1935, 1955; see also Merrill, 1960) has inferred that presently existing vertical shafts are younger than, and genetically unrelated to the major horizontal passages. Vertical shafts are found to occur only beneath the immediate vicinity where the impermeable sandstone caprock has been breached on the surface. Nearly 100 have been mapped, all appearing on the map near the base of the Cypress sandstone approximately along the 210 meter contour. Pohl reasoned that as subsurface water flows over the edge of the breached caprock, it finds its most immediate course to the base level down intersecting joints in the limestone. Down the line of intersection the solutional activity of vertically seeping water forms a vertical shaft.

It is certain that in some parts of the world vertical shafts are formed by waterfalls, as a cave stream finds or makes a breach so that it can move vertically from one level to another. It is probable that a few of the vertical shafts beneath the Mammoth Cave Plateau have been enlarged, if not formed, by waterfall action. As a waterfall retreats, it leaves a recessional gorge, and such canyon-like features have been identified underground in Iowa and Missouri. Features similar to recessional gorges are found beneath the Mammoth Cave Plateau. These gorge-like features seldom extend more than 30 meters horizontally. Except for one or two doubtful cases, they are seen to be the result of the intersection of several vertical shafts along a horizontal line, and not the result of the retreat of a waterfall. Much larger gorge-like solution canyons, morphologically and genetically similar to solutional vertical shafts, are the subject of the present investigation.

\section{Genesis of Solution Canyons}

It is evident that solution canyons are related genetically to solutional vertical shafts, forming where the intersection of the impermeable sandstone caprock permits the vertical descent of water through the jointed limestone. This breach in the caprock providing a vertical course for groundwater which had been flowing horizontally on top of the caprock is the first of three conditions necessary to the formation 
of solution canyons, and is one it shares with vertical shafts. Shafts form at the intersection of vertical joints, but the second condition necessary to the formation of solution canyons is not the intersection of joints, but the presence of one or more major vertical joints of relatively great length and depth. The third necessary condition is the presence of some means by which to concentrate a large quantity of water fairly uniformly along the joint. This condition is satisfied beneath the re-entrant valleys (figures 1 and 2). Surface runoff is conducted to the valley thalweg where a large quantity of water is lost underground. Ground water running off the impermeable top of the caprock is also concentrated for vertical descent along the valleywall intersections of the caprock. If a major joint is oriented near to, beneath, and roughly parallel to the thalweg of the valley (and thus also to the lines of intersection of the caprock by the two valley walls), then in seeking a vertical course to base level, water lost along the thalweg and along the lines of caprock intersection will descend fairly uniformly along the horizontal line of the vertical joint. Both surface and underground runoff is thus concentrated along a horizontal line. When an underlying major vertical joint is present to conduct this water to base level, the solutional activity of the vertically seeping water forms a solution canyon. At least 10 solution canyons are known in the Central Kentucky Karst, three of which will be described.

Penck Trail in the Flint Ridge Cave System is a series of solutional vertical shafts and solution canyons which extend for more than 300 meters under and parallel to, but offset from the thalweg of an overlying re-entrant valley (figure $4 \mathrm{a}$ ). Some of the shafts are coalesced along the horizontal line; other sections of Penck Trail have the features of solution canyons. Penck Trail, then, shows a form intermediate between a series of vertical shafts and a long solution canyon.

Black Canyon is a typical solution canyon in the Flint Ridge Cave System (figure 4b). Nearly 300 meters long and over 25 meters high with widths up to 12 meters, Black Canyon extends parallel to and directly below the thalweg of the overlying re-entrant valley. Along the same line downstream, and integrally connected to the solution canyon, is found the Overlook solutional vertical shaft complex. Thus, beneath the same re-entrant thalweg overlying slightly different joint conditions, a major solution canyon coalesces with a series of vertical shafts.

One of the longest solution canyons yet discovered in the Flint Ridge Cave System, Wow Canyon, is also intimately related to solutional vertical shafts (figure $4 \mathrm{c}$ ). Shaft complexes occur near both of its ends. This solution canyon runs for nearly 300 meters beneath the 


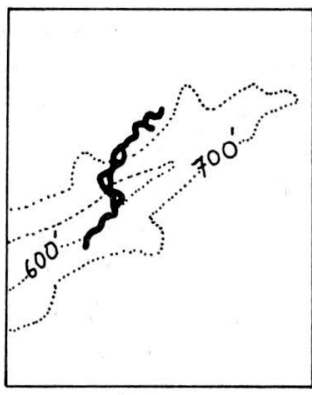

a.

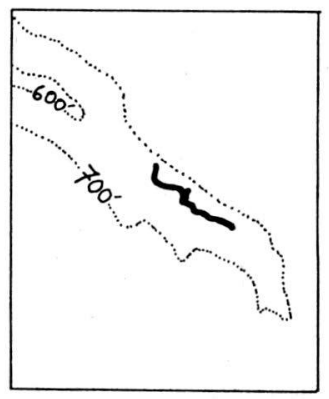

b.

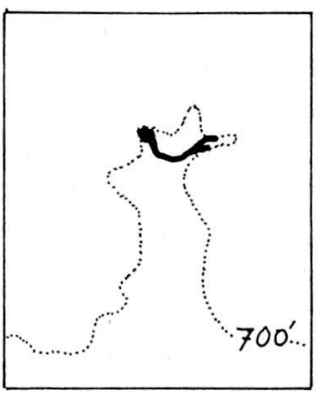

c.

\section{METERS}

Fig. 4. Maps of Solution Canyons and Solutional Vertical Shaft Series. (Traced from the map of the Flint Ridge Cave System, Smith, 1964.) a. Penck Trail. b. Black Canyon. c. Wow Canyon.

thalweg of the overlying re-entrant valley. At the upper end, the canyon averages 1.5 to 2 meters in width and 3 to 4.5 meters in height. The ceiling stays at the same level as the floor drops down a number of steps downstream, until at the lower end the canyon is 4.5 meters wide and over 25 meters high. An idealized longitudinal section illustrative of these relations is given in figure 1 . It should be noted that the diagram is somewhat deceptive, since neither the thalweg nor the joint plane is straight. The sinuous course of solution canyons is a result of the sinuosity of major joint planes, both along their horizontal and their vertical extents. Wow Canyon makes several angular turns, suggesting that in such long solution canyons, not one, but several similarly oriented major joints provide vertical water courses leading to the formation of the solution canyon.

Solution canyons, like solutional vertical shafts, can form only where there is a major vertical descent of water. Thus, both of these vertical features are concentrated beneath the edges of the ridges where the impermeable caprock is breached. Beneath the ridges under the caprock, vertical features are rare because there is no great concentration of water at high levels there seeking descent to base level. Beneath the major karst valleys there are also few major vertical features, since besides lacking means for concentration, the water is already near base level.

Like solutional vertical shafts, which enlarge vertically as well as horizontally as they evolve, solution canyons form by solution down their complete vertical extent contemporaneously. From the initiation 
of the solutional activity, water descends down the complete depth of the joint, and also along its entire horizontal extent. Enlargement of a solution canyon, then, is primarily through vertical solution down the walls, widening the solution canyon. The widening occurs first in the higher and perhaps less tight part of the joint. The increasing downstream width and height of a solution canyon is further related in general to the increasing downstream width and depth of the overlying re-entrant valley. Along any segment of the valley, more water is concentrated downstream on the thalweg than upstream. As the valley erodes headward, the upstream segments have been water courses for progressively shorter periods of time. Thus, underneath the downstream segments progressively more water over longer periods of time has been concentrated to seep down the major vertical joint, dissolving a deeper canyon there than beneath the upstream segments. This results in a solution canyon which is stepped downstream, and larger in width and height downstream, such as Wow Canyon. Thus, though a stepped solution canyon may appear to have been the result of ordinary canyon cutting by the small stream which may flow along its floor, the major depth and width of the solution canyon is due to the solutional activity of water seeping down its walls. In Wow Canyon there has undoubtedly been some lowering of the floor due to water flowing along it. The increased downstream width and height, however, is primarily related to the overlying valley which concentrates the water. It also may be that the original depth of the major Wow Canyon joint is shallower upstream, contributing to the lesser height of the canyon there. Black Canyon, for example, though slightly stepped upstream, is nearly uniform in height along its horizontal extent.

\section{Conclusion}

Solution canyons are major underground features formed by the solution of vertically seeping water down major joint planes. Their formation beneath the Mammoth Cave Plateau depends upon three necessary conditions: (1) A breached impermeable caprock which permits the vertical descent of water through the jointed limestone. (2) One or more major vertical joints of relatively great length and depth. (3) The presence of re-entrant valleys which concentrate surface and subsurface runoff along the thalweg parallel to the underlying major joint. Water concentrated along this line will seek the quickest course to base level, which will be the major joint. The solutional activity of water seeping relatively uniformly down such a joint results in the formation of a solution canyon. 


\section{SUMMARY}

Solution canyons are underground voids 1 to $15+$ meters wide, 3 to $45+$ meters high, and 30 to $300+$ meters long. Floors are stepped, ceilings level. Size increases downstream. Their course is sinuous, with some angularity. They occur parallel to and directly under or slightly offset from the thalwegs of re-entrant valleys tributary to major karst valleys. A section across a re-entrant and underlying solution canyon shows a rough hour-glass shape. Solution canyons are related genetically to solutional vertical shafts, forming where removal of the impermeable sandstone caprock permits the vertical descent of water through jointed limestone. Surface runoff concentrates along re-entrant thalwègs where a large quantity of water goes underground. This water, plus subsurface water flowing over the caprock breached by the valleys, follows the easiest route to baselevel down major vertical joints oriented parallel to the thalwegs. Solution by water seeping down these joint planes forms solution canyons.

\section{ZUSAMMENFASSUNG}

Lösungskanyons sind unterirdische Höhlen, 1-15 oder mehr Meter weit, 3-45 oder mehr Meter hoch und 30-300 oder mehr Meter lang. Der Boden ist gestuft, und die Decke ist eben. Die Größe erhöht sich in der Flußrichtung. Sie sind in der Längsrichtung gewunden mit einiger Scharfeckigkeit. Sie kommen vor parallel zu und direkt unter oder etwas zur Seite von Talwegen zurückführender Seitentäler, die in größere Karsttäler münden. Im Schnitt durch ein zurückführendes Tal und einen darunterliegenden Lösungskanyon führend, weisen sie die Form etwa eines Sanduhrglases auf. In ihrer Herkunft zeigen Lösungskanyons zu senkrechten Lösungsschichten Beziehungen, die geformt werden, wenn Entfernung des darüberliegenden undurchdringlichen Sandsteines den vertikalen Ablauf von Wasser durch den verbundenen Kalkstein möglich macht. Oberflächenwasser sammelt sich längs rückführender Talsohlen, wo große Mengen von Wasser in den Untergrund gehen. Dieses Wasser und auch das, das unterhalb der Oberfläche über den von Tälern durchbrochenen undurchdringlichen Sandstein fließt, folgt dem leichtesten Weg zum niedrigsten Niveau abwärts durch größere senkrechte Fugen, die parallel zu den Talsohlen verlaufen. Auflösung durch Wasser, welches durch diese Fugenebenen sickert, formt die Lösungskanyons.

\section{REFERENGES}

Merrill, G. K. (1960) - Additional notes on vertical shafts in limestone caves. Natl. Speleol. Soc. Bull. 22: 101-108.

Pонц, E. R. (1935) - Development of vertical shafts in limestone caves. Geol. Soc. America Proc. 1935: 96. (Abstract)

- (1955) - Vertical shafts in limestone caves. Natl. Speleol. Soc. Occasional Papers 2: 1-24.

Pонц, E. R., and Cushman, R. V. (1964) - Geologic features of the Mississippian plateaus in the Mammoth Cave area, Kentucky. Geol. Soc. Kentucky Guidebook 1964: 7-23.

Sмiтн, P. M. (1964) - The Flint Ridge Cave System: 1957-1962. Natl. Speleol. Soc. Bull. 26: 17-27, map. 